\title{
STRUCTURE OF METHYLPHEOPHORBIDE-RCI*
}

\author{
H. Scheer ${ }^{\dagger}, 1$, E. Gross ${ }^{1}$, B. NitsChe ${ }^{2}$, E. CMiel ${ }^{2}$, S. SchNeIder ${ }^{2}$, W. SchäFer ${ }^{3}$, H.-M.

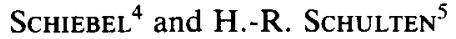 \\ ${ }^{1}$ Botanisches Institut der Universität, Menzinger Str.67, D-8000 München 19, ${ }^{2}$ Institut für \\ Physikalische Chemie, Technische Universität München, D-8046 Garching, ${ }^{3}$ Max Planck Institut für \\ Biochemie, Am Klopferspitz, D-8033 Martinsried, ${ }^{4}$ Institut für Organische Chemie, Technische \\ Universität, Hagenring 30, D-3300 Braunschweig and ${ }^{5}$ Abteilung für Spurenanalyse, Fachhochschule \\ Fresenius, Dambachtal 20, D-6200 Wiesbaden, W. Germany
}

(Received 5 September 1985; accepted 10 December 1985)

Dedicated to Prof. H. H. Inhoffen on the occasion of his 80 th birthday.

\begin{abstract}
The methanolic extract of the cyanobacterium (blue-green alga) Spirulina geitleri has been treated with methanolic acid to convert all chlorophyllous pigments to their methylpheophorbides. Fractionation of the latter from methylpheophorbide $a$ by thin layer chromatography and high pressure liquid chromatography yielded methylpheophorbide-RCI. Its structure has been determined as $13^{2} \mathrm{~S}$ hydroxy-20-chloro-methylpheophorbide $a$ by ${ }^{1} \mathrm{H}$-nuclear magnetic resonance, absorption and circular dichroism spectroscopy, mass spectrometry and by partial synthesis from chlorophyll $a$. The pigment is isolated from Spirulina geitleri irrespective of the use or omission of chlorinated substances during the isolation procedure.
\end{abstract}

\section{INTRODUCTION}

All photosynthetic energy is funneled from the bulk antenna pigments to the reaction centers, where the primary charge separation takes place. Structure and function of the reaction centers has been a prime problem in photosynthetic research. Like the antennas, they contain chlorophylls as chromophores. Quantitatively, however, the reaction centers represent only a very small percentage (generally $\leqslant 1 \%$ ) of the total pigments, and special techniques have been developed for their enrichment, selective spectroscopy and crystallization. These techniques have been most successful with the photosynthetic bacteria (Norris et al., 1978; Lubitz et al., 1984; Feher and Okamura, 1978; Hoff, 1982; Boxer et al., 1983; Deisenhofer et al., 1984).

The progress in oxygenic photosynthesis is comparably limited due to the presence of two different reaction centers, the larger size of the photosynthetic unit and in particular by the failure to isolate them hitherto free of a large number of antenna chlorophylls (Cogdell, 1983; Denblanken and Diner, 1983; Diner and Wollman, 1980; Fajer et al., 1980; Ganago et al., 1982; Haehnel, 1984; Hoff, 1982; Huang and Berns, 1981; Ikegami and Katoh, 1975; Ikegami and Ke, 1984; Ke et al., 1982; Klimov and Krasnovskii, 1981; Knaff, 1977; Nechushtai et al.,

${ }^{*}$ A preliminary report of this work has been presented at the 6th International Conference on Photosynthesis (Scheer et al., 1984).

†To whom correspondence should be addressed.

$\ddagger$ Abbreviations: Chl, chlorophyll; RCI, reaction center of photosystem I; NMR, nuclear magnetic resonance spectroscopy; $C D$, circular dichroism; $S p$. = Spirulina geitleri; tlc, thin layer chromatography; HPTLC, high performance thin layer chromatography; HPLC, high pressure liquid chromatography; MS, mass spectrometry; EI, electron impact; FD, field desorption. Qx and Qy bands are the
1983; Rutherford and Mathis, 1983; Schaffernicht and Junge, 1981; Schatz and Witt, 1984; Senger and Mell, 1977; Vacek et al., 1977; Vierling and Alberte, 1983; Yuasa et al., 1984).

It has generally been assumed that the major chlorophyll present in most antennas, e.g. chlorophyll $a$, is also present in reaction centers. A special state has been implied for this pigment in order to account for its unusual properties. For the primary donors of both PSI (P700) and PSII (P680), on which most data are available, this includes models invoking enolization and/or chelation at the isocyclic ring (Falk et al., 1975; Franck, 1961; Isenring et al., 1975; Mauzerall and Chivvis, 1973; Scheer and Katz, 1975a, 1978; Wasielewski et al., 1981), point charges in the environment (Davis et al., 1981), excited state hybridization (Fajer et al., 1973; O'Malley and Babcock, 1984), and dimerization (Bucks and Boxer, 1982; Feher et al., 1975; Katz et al., 1978; Norris et al., 1971; Wasielewski, 1982). In particular the latter model has been reinforced by the recent verification of a special pair of bacteriochlorophylls $b$ in the reaction center from the photosynthetic bacterium, Rhodopseudomonas viridis (Deisenhofer et al., 1984). Tetrapyrrolic pigments (chlorophylls or pheophytins) have also been implied as the primary acceptors in both photosystems, although much less is known about their properties and hence their structures (see e.g. Fajer et al., 1980; Haehnel, 1984; Ikegami and Ke, 1984; Klimov and Krasnovskii, 1981; Shuvalov et al., 1979).

A distinctly different origin for the unusual properties of reaction center chlorophylls would be differences in their molecular structure, which go beyond essentially reversible changes like e.g. enolization. This view has gained new interest by the recent finding of a new chlorophyll by Dörnemann and Senger $(1981,1982)$. It has been named chlorophyll$\mathrm{RCI}(\mathrm{Chl}-\mathrm{RCI}) \ddagger$ due to its red shifted absorption 
spectrum and in particular due to its quantitative correlation with $\mathrm{P} 700$ in a variety of organisms from Prochloron to spinach (Dörnemann and Senger, 1985). From a comparison of a sample of this chlorophyll with known chlorophylls, it has been suggested that it contains a substituent at C-20, similar to the bacteriochlorophylls 660 (chlorobium chlorophylls). Subsequently, somewhat larger amounts of Chl-RCI have been isolated from the blue-green alga, Spirulina geitleri, and converted to its methylpheophorbide. The structure of the latter has been proposed as $13^{2}$-hydroxy-20-chloro methylpheophorbide $a$ (Scheer $e t$ al., 1984). The 20-chloro substituent has recently also been shown to be present in the parent chlorophyll (Dörnemann and Senger, 1985). Here, we wish to report further results on the structure of methylpheophorbide- $\mathrm{RCI}$ including its stereochemistry and partial synthesis starting from chlorophyll $a$. The accompanying report (Dörnemann and Senger) deals with structural investigations on the parent pigment, e.g. chlorophyll-RCI. The results of both studies is the structure of chlorophyll-RCI as $13^{2}$ (S)-hydroxy-20-chloro-chlorophyll $a$.

\section{MATERIALS AND METHODS}

All chemicals were reagent grade. The solvents were reagent grade and/or distilled prior to use. Spray-dried $S p$. geitleri from lake Texcoco (Mexico) was purchased from W.Behr Importe, Bonn. Pheophytin 'Sandoz' was a gift of Professor H. H. Inhoffen, formerly Braunschweig. Pheophytin $a$, methylpheophorbide $a$ and pyromethylpheophorbide $a$ were prepared by standard procedures (Fischer and Stern, 1940; Pennington et al., 1964).

Analytical tlc was done on pre-coated HPTLC plates (Merck, Darmstadt) either on silica or on RP-8 phase. Silica $\mathrm{H}$ (Merck, Darmstadt) was used for preparative tlc $(20 \times 20$ $\mathrm{cm}$ plates, $0.75 \mathrm{~mm}$ adsorbent). The HPLC system consisted of two M6000A pumps with a gradient programmer (Waters, Königstein) and two model spectro monitor II detectors (LDC-Latek, Heidelberg). Columns $(4 \times 300$ $\mathrm{mm}$ ) were filled with Lichrosorb RP8 (Merck, Darmstadt). Silica ' $H$ ' (Merck, Darmstadt) was used for conventional preparative column chromatography.

$U V$-visible spectra were recorded on a model DMR22 (Zeiss, Oberkochen) or PE320 (Perkin-Elmer, Ueberlingen) spectrophotometer, fluorescence spectra on the model DMR22, circular dichroism spectra on a dichrograph $\mathrm{V}$ (ISA-Jobin-Yvon, Harlaching). Mass spectra were recorded mode on a CH7A coupled to a data system SS200MS (Varian-MAT, Bremen), or on a model 731 (Varian-MAT, Bremen) in the EI ionization mode, and on a model 731 with SS200 MS data system (Finnigan-MAT) and Canberra multichannel analyzer in the field desorption mode.

' $H$-NMR spectra were recorded on a model WP80 or WH500 (Bruker, Karlsruhe, we thank the company for providing to us measuring time on the WH500 spectrometer) in the pulse-FT mode.

\section{Isolation of methylpheophorbide-RCI:}

Method I. Spray-dried $S p$. geitleri $(50 \mathrm{~g})$ was extracted with methanol $(100 \mathrm{~m} \ell)$ at room temperature. The filtrate was set aside in the refrigerator, and the residue extracted three more times with methanol. To the combined extracts containing $180 \mathrm{mg}$ chlorophyll $a$, hydrochloric acid (36\%) was added dropwise under shaking to a final concentration of $1 \%$. An equal volume of methylene chloride was added without delay, and then saturated sodium bicarbonate until the phases separated. The organic phase was washed neutral, dried over sodium chloride, and evaporated to dryness. The crude pheophytin mixture was filtered over silica and then subjected to column chromatography (carbon tetrachloride with acetone increasing from 98:2 to 96:4). The fractions were assayed by difference spectroscopy against pure pheophytin $a$. The red-shifted fractions trailing behind pheophytin $a$ were pooled, evaporated to dryness and transesterified to the methylpheophorbides by refluxing for $30 \mathrm{~min}$ in methanolic sulfuric acid ( $5 \% \mathrm{vol} / \mathrm{vol})$ under nitrogen. The resulting mixture was first separated by column chromatography (carbon tetrachloride with aceton increasing from $98: 2$ to $96: 4$ ) followed by preparative tlc (same mixture $90: 10$ ) to yield two poorly separated fractions with a red-shifted absorption spectrum migrating between methylpheophorbide $a$ and its epimeric $13^{2}$ hydroxy derivatives. They were separated by HPLC (methanol, detection at 662 and $680 \mathrm{~nm}$ ), and finally freed from colorless impurities bleeding from the HPLC column by a second preparative tlc. Combined yield of fractions $A$ (slower migrating) and B (faster migrating): $16 \mu g$ (determined by absorption spectroscopy under the assumption of the same extinction coefficient $\left(60000 \mathrm{M}^{-1} \mathrm{~cm}^{-1}\right)$ as methylpheophorbide $a$ ). The ratio of the two fractions is estimated $1: 4$. Only fraction $B$ was obtained in pure form.

$\mathbf{R}^{\mathrm{f}}$-values: silica with carbon tetrachloride-acetone $=$ $90: 10$ : fraction A: 0.25 , fraction B: 0.33 ; RP-8 with methanol: fraction $A: 0.24$, fraction $B: 0.24$. Retention times $(4.6 \times 300 \mathrm{~mm}$ LiChrosorb RP-8, $10 \mu$, methanolwater $=95: 5,1.5 \mathrm{m \ell} / \mathrm{min})$ : fraction A: $8.8 \mathrm{~min}$, fraction $B$ : $9.7 \mathrm{~min}$

UV-vis of fractions A and B: methanol: 675(1.0), 612(0.16), 542(0.29), 510(0.25), $407 \mathrm{~nm}(2.5)$; acetone: 673(1.0), 612(0.08), 540(0.25), 510(0.23), 409(3.4).

${ }^{1} \mathrm{H}-\mathrm{NMR}$ of fraction $\mathrm{B}$ in $\mathrm{C}^{2} \mathrm{HCl}(500 \mathrm{MHz}, \mathrm{c}=80 \mu \mathrm{M})$ : $10.0,9.95$ (s, $1 \mathrm{H}$ each, 5,10-H), 8.0(dd, $1 \mathrm{H}$, vinyl-Hx), 6.4(dd, $1 \mathrm{H}$, vinyl-Ha), 6.2(dd, $1 \mathrm{H}$, vinyl- $\mathrm{Hb}), 5.75(\mathrm{~s}, 1 \mathrm{H}$, $\left.13^{2} \mathrm{OH}\right), 4.5,4.2(\mathrm{~m}, 1 \mathrm{H}$ each, 17,18-H) $3.85,3.75,3.7$, $3.6,3.3\left(\mathrm{~s}, 3 \mathrm{H}\right.$ each, $\left.2,7,12,13^{4}, 17^{4}-\mathrm{CH}_{3}\right), 3.9(\mathrm{q}, 2 \mathrm{H}$, $\left.8 \mathrm{CH}_{2}\right), 1.8\left(\mathrm{t}, 3 \mathrm{H}, 8^{1} \mathrm{CH}_{3}\right), 1.5\left(\mathrm{~d}, 3 \mathrm{H}, 18 \mathrm{CH}_{3}\right)$.

MS of fraction B: FD-mode: $m / z \quad 656\left({ }^{12} \mathrm{C}_{36} \mathrm{H}_{37} \mathrm{~N}_{4}\right.$ $\mathrm{O}_{6}{ }^{35} \mathrm{Cl}, 100 \%$ relative abundance $), 657\left(1 \times{ }^{13} \mathrm{C}, 42.8 \%\right)$, $658\left(2 \times{ }^{13} \mathrm{C}\right.$ or $\left.{ }^{37} \mathrm{Cl}, 41.4 \%\right), 659\left(3 \times{ }^{13} \mathrm{C}\right.$ or $1 \times{ }^{13} \mathrm{C}$ plus $\left.{ }^{37} \mathrm{Cl}, 15.5 \%\right), 660\left(4 \times{ }^{13} \mathrm{C}\right.$ or $2 \times{ }^{13} \mathrm{C}$ plus $\left.{ }^{37} \mathrm{Cl}, 4.2 \%\right)$. Theoretical ratios for the isotopic distribution $\mathrm{C}_{36} \mathrm{H}_{37} \mathrm{~N}_{4} \mathrm{O}_{6} \mathrm{Cl}: \mathrm{M}: \mathrm{M}+1: \mathrm{M}+2: \mathrm{M}+3: \mathrm{M}+4=$ $100: 42.3: 41.9: 15.2: 3.4$. The found values are given in Fig. 3D. El-mode: $656(\mathrm{M}, 100 \%$, isotope ratio similar as in FD spectrum $), 641\left(-\mathrm{CH}_{3}, 7 \%\right), 598\left(-\mathrm{COOCH}_{3}, 48 \%\right), 659$ $\left(-\mathrm{CH}_{2} \mathrm{CH}_{2} \mathrm{COOCH}_{3}, 28 \%\right), 537\left(-\mathrm{CH}_{2} \mathrm{CH}_{2} \mathrm{COOCH}_{3}\right.$, $\left.-\mathrm{CH}_{2} \mathrm{OH}, 22 \%\right), 511 \mathrm{~m} / \mathrm{z}\left(-\mathrm{COOCH}_{3},-\mathrm{CH}_{2} \mathrm{CH}_{2}-\right.$ $\mathrm{COOCH}_{3}, 10 \%$ ); isotope ratios for all fragments similar as for molecular ion.

CD spectra of fractions A and B see Fig. 5 and Table 2.

Fluorescence ( $\lambda_{\max }$, emission in methanol): fraction $\mathrm{B}$ : $681 \mathrm{~nm}$, relative yield as compared to methylpheophorbide $a=36 \%$; fraction A: $\lambda_{\max }=681 \mathrm{~nm}$, relative yield $=0.26$.

Method II. $100 \mathrm{~g}$ spray-dried $S p$. geitleri were extracted as in method $A$, and the crude extract containing $380 \mathrm{mg}$ chlorophyll $a$ worked up with the following changes to method I: The demetalation was done with phosphoric acid instead of hydrochloric acid, sodium sulfate was used as drying agent instead of sodium chloride, toluene was used instead of carbon tetrachloride and methylene chloride for all work-ups and chromatographies. The replacement made some adjustments of the mobile phases for chromatography necessary, generally an increase of the acetone in the mixtures by approx. $3 \%$.

Combined yield of fraction A and B: $20 \mu \mathrm{g}$. The purified fraction $B$ was identical to fraction B obtained by method I according to chromatographic mobilites, UV-vis absorption and fluorescence spectra.

Method III. Prepurified chlorophyll-RCI from Scenedes- 
mus obliquus ( $12 \mu \mathrm{g}$ of a sample containing $\geq 75 \%$ chlorophyll-RCI, provided by Dr. D. Dörnemann in the laboratory of Professor H. Senger) were dissolved in chloroform $(0.5 \mathrm{~m} \ell)$ and flushed with Ar. Methanolic sulfuric acid $(5 \%$ $\mathrm{vol} / \mathrm{vol}$, flushed with Ar) were added, and the mixture refluxed under Ar for $30 \mathrm{~min}$. The reaction mixture was washed neutral, dried and chromatographed by HPLC and subsequent tlc as above. The combined yield of fractions $A$ and $B$ was $4 \mu \mathrm{g}$. The purified fraction $A$ was identical with fraction $A$ obtained by the other methods with respect to chromatographic mobilities, UV-vis absorption and fluorescence spectra

\section{$13^{2}$-Hydroxy-methylpheophorbide a}

(a) From pheophytin 'Sandoz'. Column chromatography on silica with carbon tetrachloride with acetone increasing from $98: 2$ to $94: 6$ after elution of pheophytin $a$, yields the isomer mixture of $13^{2}$-hydroxy pheophytin $a$ containing some pheophytin $b$ and/or its $13^{2}$-hydroxy analogue. The mixture was refluxed for $30 \mathrm{~min}$ in methanolic sulfuric acid $(5 \%, \mathrm{vol} / \mathrm{vol})$. The crude product obtained after work-up, was dissolved in $30 \mathrm{~m} \ell$ formic acid $(85 \% \mathrm{vol} / \mathrm{vol}$ in water) and extracted with carbon tetrachloride $(25 \mathrm{~m} \ell)$. Water $(1.25 \mathrm{~m} \ell)$ was added to the formic acid, which was extracted twice with carbon tetrachloride ( $25 \mathrm{~m} \ell$ each). The aqueous phase was treated with water $(100 \mathrm{~m} \ell)$ and extracted with dichloromethane. The final purification requires preparative tlc (toluene/acetone $=9: 1$ ).

(b) From methylpheophorbide a. Following the method of Schmidt (1985), methylpheophorbide $a(20 \mathrm{mg})$ is dissolved in hot chloroform $(100 \mathrm{~m} \ell)$ and combined with a refluxing saturated solution of zinc acetate in methanol ( 100 $\mathrm{m} \ell$ ). The mixture is refluxed under air for $15 \mathrm{~min}$ and then extracted with water. Concentrated hydrochloric acid is added to the chloroform phase to a final concentration of $15 \%$. After washing to neutral and drying, the chloroform phase is chromatographed by preparative tlc (carbon tetrachloride/acetone $=9: 1$ ). The rapidly migrating zone contains methylpheophorbide $a$, the slower migrating zone an epimer mixture of $13^{2}$-hydroxy-methylpheophorbide $a$. UV-vis absorption in diethylether: $665(1.0), 606(0.14)$, $528(0.16), 495(0.25), 405 \mathrm{~nm}(2.0)$.

\section{Chlorination of pheophorbides at C-20: general procedure}

The general procedure outlined by Woodward and Skaric (1961) was used. The pheophorbide was dissolved in diethylether (approx. $10 \mathrm{m \ell} / \mathrm{mg}$ ). An equal volume of hydrochloric acid (16\% for methylpheophorbides, $30 \%$ for pheophytins of the $a$-type) was added under gentle stirring, which transfers the pigment into the aqueous phase. The stirring was continued, and three portions of hydrogen peroxide $(4 \mu \ell / \mathrm{mg}$ pigment each) were added immediately, and then after 30 and $60 \mathrm{~min}$. After $90 \mathrm{~min}$, most of the pigment is transferred back into the diethylether, which is separated from the aqueous phase, washed neutral, dried and evaporated in vacuum.

\section{0-Chloro-pyromethylpheophorbide a}

The reaction product is purified by preparative tlc (carbon tetrachloride/acetone $=94: 6$ ), and the plates dried well before scraping off the bands. The major, brownishviolet band yields 20-chloro-pyromethylpheophorbide $a$ $(70 \%)$.

UV-vis absorption in diethylether: 672(1), 614(0.14), $552(0.29), 520(0.21), 416 \mathrm{~nm}(2.32)$; in acetone: $673(1.0)$, $614(0.11), 543(0.3), 511(0.21), 406 \mathrm{~nm}(2.18)$.

${ }^{1} \mathrm{H}-\mathrm{NMR}$ in $\mathrm{C}^{2} \mathrm{HCl}_{3}: 9.68(\mathrm{~s}, 2 \mathrm{H}, 5,10-\mathrm{H}), 7.93(\mathrm{dd}, 1 \mathrm{H}$, vinyl-Hx), 6.33(dd, $1 \mathrm{H}$, vinyl-Ha), 6.15 (dd, $1 \mathrm{H}$, vinyl- $\mathrm{Hb}$ ), $5.28\left(\mathrm{~s}, 2 \mathrm{H}, 13^{2}-\mathrm{H}\right), 4.85(\mathrm{q}, 1 \mathrm{H}, 18-\mathrm{H}), 4.29(\mathrm{~m}, 1 \mathrm{H}, 17-\mathrm{H})$, $3.8\left(\mathrm{q}, 2 \mathrm{H}, 8-\mathrm{CH}_{2}\right), 3.77,3.63,3.63,3.30(\mathrm{~s}, 3 \mathrm{H}$ each, $\left.2,7,12,17^{4}-\mathrm{CH}_{3}\right), 1.76\left(\mathrm{t}, 3 \mathrm{H}, 8^{1}-\mathrm{CH}_{3}\right), 1.68(\mathrm{~d}, 3 \mathrm{H}, 18-$ $\left.\mathrm{CH}_{3}\right),-1.9 \mathrm{ppm}(\mathrm{s}, 2 \mathrm{H}, \mathrm{NH})$.
MS: $m / z 582\left(100 \%, \mathrm{M}\right.$ for ${ }^{12} \mathrm{C}_{36} \mathrm{H}_{37} \mathrm{~N}_{4} \mathrm{O}_{6}{ }^{35} \mathrm{Cl}$, isotope peaks $583=39.7 \%, 584=41.1 \%, 585=15.2 \%, 586=$ $2.9 \%), 567\left(5.9 \%,-\mathrm{CH}_{3}\right.$, isotope peak ratios as $\left.\mathrm{M}^{+}\right)$, $548(11.3 \%$, no $\mathrm{Cl}$ isotope pattern, probably educt), $495\left(40.2 \%,-\mathrm{CH}_{2} \mathrm{CH}_{2} \mathrm{COOCH}_{3}\right.$, isotope peak ratios as $\mathrm{M}^{+}$). Fluorescence in methanol: $\lambda_{\max }$, emission $=681 \mathrm{~nm}$, relative quantum yield $v s$ pyromethylpheophorbide $a=$ $22 \%$. Circular dichroism in methanol $\left(\lambda_{\max },[\odot] \times 10^{-3}\right)$ : $679(-45.4), 547(19.4), 505(3.1), 411(89.3), 369(-9.4)$, $333(+25.0), \quad 301(-26.6), \quad 281(-25.0), 227 \mathrm{~nm}(-40.7$ $\left.\mathrm{grad} \cdot \mathrm{M}^{-1} \mathrm{~cm}^{-1}\right)$.

A slightly faster migrating by-product can be isolated in varying yields. Its absorption spectrum is similar to that of 20-chloro-pyromethylpheophorbide $a$. It is more mobile than the latter both on silica and reverse phase tlc.

\section{0-Chloro-methylpheophorbide a}

The reaction was carried out in exactly the same way as described for 20-chloro-pyromethylpheophorbide $a$. Yield: $44 \%$. Retention time (HPLC on $4.6 \times 300 \mathrm{~mm}$ LiChrosorb RP8, methanol-water $=92: 8,1.5 \mathrm{~m} \ell / \mathrm{min}): 5.8 \mathrm{~min}$, retention time of methylpheophorbide $=5.4 \mathrm{~min}$.

UV-vis absorption in methanol 674(1), 613(0.18), 544(0.39), 513(0.35), 412(2.97), $383 \mathrm{~nm}(2.18$, shoulder). ' $\mathrm{H}$-NMR in $\mathrm{C}^{2} \mathrm{HCl}_{3}$ : 9.81(s, $\left.2 \mathrm{H}, 5,10-\mathrm{H}\right), 7.95$ (dd, vinyl$\mathrm{Hx}), 6.35(\mathrm{dd}, 1 \mathrm{H}$, vinyl-Ha), $6.2(\mathrm{dd}, 1 \mathrm{H}$, vinyl-Hb), 6.28( $\mathrm{s}$, $\left.1 \mathrm{H}, 13^{2}-\mathrm{H}\right), 4.9(\mathrm{~m}, 1 \mathrm{H}, 18-\mathrm{H}), 4.3(\mathrm{~m}, 1 \mathrm{H}, 17-\mathrm{H})$, $3.92,3.74,3.74,3.57,3.33\left(\mathrm{~s}, 3 \mathrm{H}\right.$ each, $\left.2,7,12,13^{4}, 17^{4}-\mathrm{CH}_{3}\right)$, $1.72\left(\mathrm{t}, 3 \mathrm{H}, 8^{1}-\mathrm{CH}_{3}\right), 1.68 \mathrm{ppm}\left(\mathrm{d}, 3 \mathrm{H}, 18-\mathrm{CH}_{3}\right)$.

20-Chloro-methylpheophorbide $a$ is accompanied by two intermediates (see results) in varying yields. Retention times on the same system: Intermediate I: $4.4 \mathrm{~min}$, intermediate (major fraction) II: $8.2 \mathrm{~min}$. Mass spectrum of fraction II: $m / z 674$ (highest mass in spectrum, $100 \%$, isotope peaks $675(42 \%), 676(66 \%), 677(31 \%), 678(16 \%)$ ), $640(20 \%$, probably monochlorinated pigment $), 616(100 \%$, $-\mathrm{COOCH}_{3}$, similar isotope peaks as $\left.\mathrm{M}^{+}\right), 582(35 \%, \mathrm{~m} / \mathrm{z}$ $640-\mathrm{COOCH}_{3}$ ).

\section{$13^{2}$-Hydroxy-20-chloro-pheophytin a}

$13^{2}$-Hydroxy-pheophytin $a$ is chlorinated by the standard procedure, except that the hydrochloric acid is $30 \%$. Rf on silica (toluene/acetone $=85: 15$ ): $0.32 ;$ pheophytin $a=$ 0.36 . Absorption in methanol: $676(1.0), 614(0.1)$, $542(0.27), 513(0.23), 412(2.2)$. A product identical with respect to chromatographic mobilities and UV-vis spectrum is obtained by demetalation of chlorophyll-RCI from Scenedesmus obliquus provided to us by D. Dörnemann.

\section{$13^{2}$-Hydroxy-20-chloro-methylpheophorbide a}

The crude product obtained by the general procedure from the epimer mixture of $13^{2}$-hydroxymethylpheophorbide $a$ was worked up and chromatographed on silica plates (toluene/acetone $=9: 1$ ) to yield two fractions containing $13^{2} \mathrm{~S}$ - (fraction $\mathrm{B}$ ) and $13^{2} \mathrm{R}$-hydroxy20-chloro-methylpheophorbide $a$ (fraction $\mathrm{A}$ ) in a ratio of $20: 1$. Fraction $B\left(13^{2} \mathrm{~S}\right)$ : UV-vis in methanol: $675(1.0)$, 614(0.12), 542(0.26), 511(0.2), 408(2.0). ${ }^{1} \mathrm{H}-\mathrm{NMR}(4 \mathrm{~m} M$ in $\left.\mathrm{C}^{2} \mathrm{HCl}_{3}\right): 9.70(\mathrm{~s}, 2 \mathrm{H}, 5,10-\mathrm{H}), 8.0(\mathrm{dd}, 1 \mathrm{H}$, vinyl- $\mathrm{Hx})$, $6.35(\mathrm{dd}, 1 \mathrm{H}$, vinyl-Ha) $, 6.15(\mathrm{dd}, 1 \mathrm{H}$, vinyl- $\mathrm{Hb}), 5.5(\mathrm{~s}, 1 \mathrm{H}$ exchangeable with $\left.{ }^{2} \mathrm{H}_{2} \mathrm{O}, 13^{2} \mathrm{OH}\right), 4.15,4.85(\mathrm{~m}, 1 \mathrm{H}$ each, $17,18-\mathrm{H}), 3.8,3.75,3.7,3.63,3.3(\mathrm{~s}, 3 \mathrm{H}$ each, $\left.2,7,12,13^{4}, 17^{4}-\mathrm{CH}_{3}\right), 3.8\left(\mathrm{q}, 2 \mathrm{H}, 8-\mathrm{CH}_{2}\right), 1.5(\mathrm{~d}, 3 \mathrm{H}, 18$ $\left.\mathrm{CH}_{3}\right), 1.7\left(\mathrm{t}, 3 \mathrm{H}, 8^{3} \mathrm{CH}_{3}\right)$.

Mass spectrum: EI-mode: $m / z 656(100 \%, M$ for $\mathrm{C}_{36} \mathrm{H}_{37} \mathrm{~N}_{4} \mathrm{O}_{6} \mathrm{Cl}$, isotope peaks: $657(42 \%), 658(38 \%)$, $659(13 \%), 660(3.5 \%)$; major fragments: $641(5 \%)$, $597(47 \%), 569(28 \%), 537(31 \%), 511(8 \%)$. See methylpheophorbide-RCI fraction A for assignments. Circular dichroism spectra: See Fig. 5 and Table 2. Fluorescence: $\lambda_{\text {max }}$ in methanol: $681 \mathrm{~nm}$; relative yields as compared to methylpheophorbide $a$ : Fraction $\mathrm{B}=36 \%$, fraction $\mathrm{A}=$ 
$26 \%$. The same yields were obtained in ether.

The products are accompanied by two slightly more mobile products (on silica), in particular if the pigments were let dry on silica during the preparative tlc. $R f$ on silica (toluene/acetone $=9: 1$ ): 0.33 and 0.38 , respectively. (132-hydroxy-20-chloro-methylpheophorbide $a: 0.30$, 0.35). Absorption of the mixture (in methanol): $677(1.0)$, 614(0.09), 542(0.22), 510(0.16), 408(1.8), 376(1.15,sh).

${ }^{1} \mathrm{H}$-NMR of the mixture (in $\mathrm{C}^{2} \mathrm{HCl}_{3}$ ): $9.75,10.2(\mathrm{~s}, 5,10-$ $\mathrm{H}), 4.88(\mathrm{q}, 18-\mathrm{H}), 4.2(\mathrm{~m}, 17-\mathrm{H}), 3.78,3.65,3.65,3.35(\mathrm{~s}$, 4-5 $\left.\mathrm{CH}_{3}\right), 1.75 \mathrm{ppm}\left(\mathrm{t}, 8^{1}-\mathrm{CH}_{3}\right)$. No vinyl signals.

\section{RESULTS}

The isolation procedure for methylpheophorbide$\mathrm{RCI}$ is outlined in Fig. 1. The source for the extraction, e.g. the blue-green alga (cyanobacterium) Spirulina geitleri was chosen because it is readily available in large quantities and contains no $\mathrm{Chl} b$, which interferes with the chromatographic purification. After several-fold extraction of the spray-dried powder with cold methanol, which removes more than $90 \%$ of the chlorophyllous pigments, the crude extract was transferred to methylene chloride and demetalated without delay. All fractions from the column chromatography were assayed by difference spectroscopy against pheophytin $a$. The first component with a red-shifted absorption spectrum eluted just before pheophytin $a$, the second one after pheophytin $a$. Both could not be obtained in pure form at this stage. The purest fractions have a double-peaked red absorption $\left(\lambda_{\max }=665\right.$ and 695 $\mathrm{nm})$. A third fraction with a distinctly red-shifted absorption maximum $\left(\lambda_{\max }=680 \mathrm{~nm}\right)$ elutes after $13^{2}$-hydroxy pheophytin $a$. It is a metal complex if judged from its absorption spectrum, but the metal is

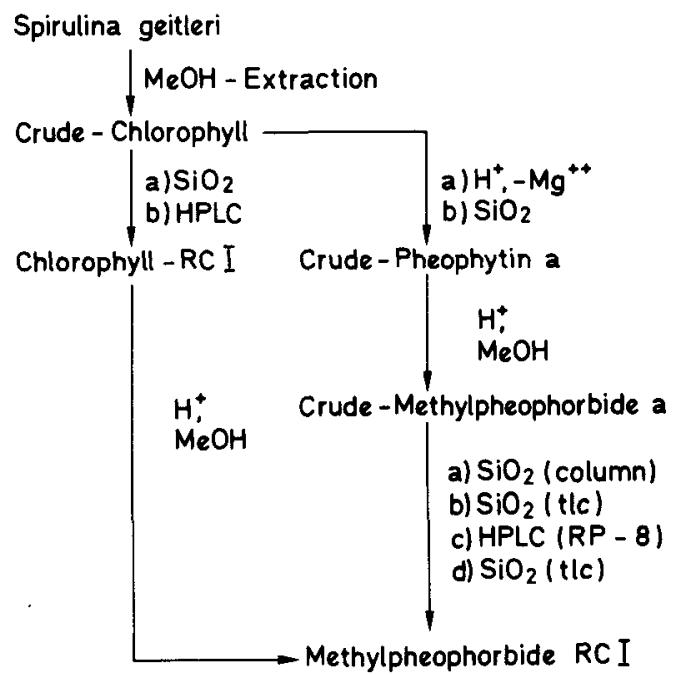

Figure 1. Isolation scheme of methylpheophorbide-RCI. The right branch was used for the isolation of the pigment from Spirulina geitleri. A sample of chlorophyll-RCI from Scenedesmus, kindly provided to us from D. Dörnemann, was transformed to methylpheophorbide-RCI via the left branch. much more strongly bound than magnesium and stable against cold $16 \%$ hydrochloric acid. It was not characterized in any more detail. Other minor red-shifted components were occasionally observed but not examined further.

After transesterification with acidic methanol, the resulting methylpheophorbides were fractionated by a series of chromatographic steps involving subsequently silica gel, then a reverse phase adsorbent, and finally again silica gel to remove any material bleeding from the reverse phase HPLC column. The first column was again assayed by difference spectroscopy (against methylpheophorbide $a$ ), later on a direct assay for the desired product was possibly by absorption spectroscopy.

In method $(\mathrm{A})$, the isolation was carried out using many chlorinated reagents which are commonly used in chlorophyll chemistry, e.g. hydrochloric acid for demetalation, sodium chloride for drying, and carbon tetrachloride for chromatography on silica. To ascertain that the chlorine atom was not introduced inadvertently during the extraction and derivatisation, all chlorinated reagents have been replaced in method (B). Whereas the same compounds were isolated, the yield of methylpheophorbide-RCI obtained with method $B$ is decreased as compared to method $\mathrm{A}(0.2 v s 0.3 \mu \mathrm{g} / \mathrm{g}$ dry weight $)$. The toluene based eluents are, however, in many cases inferior to the ones based on carbon tetrachloride. The smaller yield is thus most likely due to losses during the isolation procedure rather than to less material being present from the beginning.

\section{Absorption spectra}

The spectrum of chlorophyll-RCI is somewhat red-shifted, but otherwise quite similar to that of chlorophyll $a$. There is a series of substituent changes known to produce long-wavelength shifted absorptions in chlorophylls (see Fig. 2), including unsaturation of the 8-ethyl- to a vinyl-substituent (Wu and Rebeiz, 1984; Bazzaz and Brereton, 1982; Budzikiewicz and Taraz, 1971; Dougherty et al., 1970), the introduction of electron-withdrawing substituents at C-3 (but not C-7) like the formyl group suggested for chlorophyll $d$ (Holt and Morley, 1959) or mesosubstitution at $\mathrm{C}-20$ as in the bacteriochlorophylls $c$ (chlorobium chlorophylls-660) (Holt et al., 1962; Smith et al., 1980). These substituent changes show, however, distinct differences in a) the relative shift of the Qy and the major Soret transitions, and b) in the relative intensities of these two bands (Fig. 2). If judged from these criteria, the absorption spectrum of chlorophyll-RCI indicates the presence of a mesosubstituent as in the bacteriochlorophylls $c$. The spectral changes between the former and chlorophyll $a$ are very similar to the changes between the latter and the bacteriochlorophylls $d$. This structural relationship is supported from a comparison of the respective methylpheophorbides. In addition to the major Qy and Soret bands, the demetalated pigments 

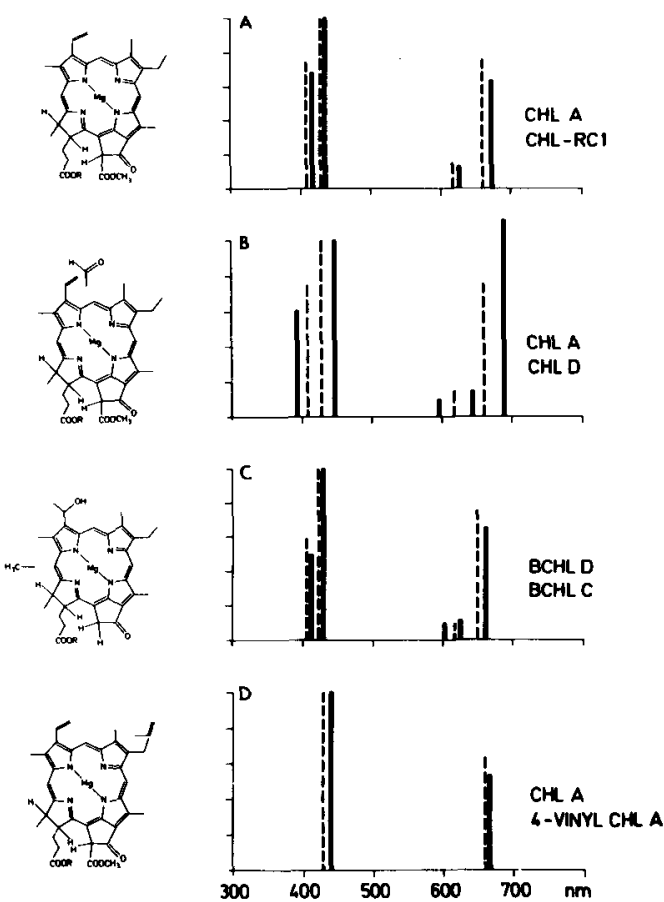

Figure 2. Absorption spectra of red-shifted chlorophylls. Stick spectra of pairs of chlorophyll derivatives differing by a single substituent which induces a red shift in the absorption spectrum. The dotted spectra correspond to the parent structures shown at the left side in full, e.g. chlorophyll $a(\mathrm{~A}, \mathrm{~B}, \mathrm{D})$ and bacteriochlorophyll $d(\mathrm{C})$, the solid spectra to the partial structures.

show additional absorptions of moderate intensity in the $500-600 \mathrm{~nm}$ spectral region. A particular feature of the bacteriomethylpheophorbides $c$ is the intensity ratio of the $\mathrm{Qx}(0-0)$ and the $\mathrm{Qy}(0-1)$ bands located around 510 and $540 \mathrm{~nm}$, respectively. In contrast to the methylpheophorbide $a$-type pigments, the longer-wavelength band of these two is more intense in the $\delta$-substituted pigments, and the same feature is found in the methylpheophorbides-RCI, too.

\section{Mass spectra}

The mass spectrum of methylpheophorbide-RCI shows a molecular ion $(\mathrm{m} / \mathrm{z} 656)$ which is 50 mass units heavier than that of methylpheophorbide $a$. The fragmentation pattern of the electron impact spectrum is very similar to that of methylpheophorbide $a$. It is dominated by loss of the $13^{2}$. carbomethoxy substituent and benzylic fragmentations (loss of methyl groups (C-8 $\left.{ }^{1}, C-18\right)$ or the propionic acid side chain). Most of the ions show an unusual intensity pattern with intense $\mathrm{X}+1, \mathrm{X}+2$, $\mathrm{X}+3$ ions, similar to the molecular ion region of the field desorption mass spectrum shown in Fig. 3. $M+2$ ions are frequently observed in the electron impact spectra of porphyrins due to hydrogenation in the ion source (Budzikiewicz, 1978), and the intensities are also not very accurate due to the low intensity of the molecular ion cluster (Fig. 3A). The molecular ion pattern is nonetheless only readily compatible with the presence of a chlorine atom in the molecule, which is verified by the field desorption spectrum (Figs. 3C and D). The fragmentations and molecular ion patterns of electron impact spectra of the 20 chlorinated model compounds are also similar to those of methylpheophorbide-RCI (not shown, see materials and methods for data). In particular is the loss of the chlorine atom at C-20 not a prominent fragmentation of any of them. These data suggest a chlorine atom is a meso-substituent in methylpheophorbide-RCI.

From the remaining mass difference of 16 mass units, an oxygen atom is suggested as the second difference as compared to methylpheophorbide $a$. The resulting formula $\mathrm{C}_{36} \mathrm{H}_{37} \mathrm{~N}_{4} \mathrm{O}_{6} \mathrm{Cl}$ is ascertained by the high-resolution analysis of the molecular ion obtained by peak matching (found: $656.240 \pm 2 \mathrm{ppm}$ for $\mathrm{C}_{36} \mathrm{H}_{37} \mathrm{~N}_{4} \mathrm{O}_{6}{ }^{35} \mathrm{Cl}$ ).

\section{${ }^{1} H-N M R$ spectra}

The most significant changes in the NMR spectrum of methylpheophorbide-RCI vs that of methylpheophorbide $a$, is the absence of the C-20 methine proton, and a high-field shift of the $13^{2}-\mathrm{H}$. All other signals are present in both compounds and show only minor shifts. In combination with the mass spectra, this leaves either an $\mathrm{OH}$-group at $\mathrm{C}-13^{2}$ and a $\mathrm{Cl}$-substituent at $\mathrm{C}-20$, or vice versa. Compounds with a 20-chloro substitution are well known (Woodward and Skaric, 1961; Hynninen and Lötjönen, 1981). The NMR data reported earlier and the data obtained for the two model compounds in this study, e.g. the 20-chloro-methylpheophorbides $a$ (see also Hynninen and Lötjönen, 1981) and the 20-chloropyromethylpheophorbide $a$, are readily compatible with the first structure, e.g. $\mathrm{Cl}$ at $\mathrm{C}-20$. This substitution pattern is also supported by the finer spectral details, in particular the distinct low-field shifts of the resonances related to the substituents at $\mathrm{C}-2$ and $\mathrm{C}-18$. The $18-\mathrm{H}$ and $18-\mathrm{CH}$ signals are unambiguously identified by their multiplicities (Scheer and Katz, 1975), the assignment for the $2-\mathrm{CH}_{3}$ signal is tentative and based on the fact that it is usually the $\mathrm{CH}_{3}$-singlet occurring at the highest field (Scheer and Katz, 1975).

The high-field shift of the $13^{2}-\mathrm{H}$ signal is also compatible with the replacement of $\mathrm{H}$ by $\mathrm{OH}$, because very similar shifts have been reported to the $\mathrm{OH}$ resonances in $13^{2}$-hydroxy-chlorophyll $a$ (Schmidt, 1985; the different value reported by Schaber et al. (1985) is most likely due to the different solvent, e.g. acetone, as compared to chloroform used in the other studies) and $13^{2}$-hydroxybacteriochlorophyll a (Brereton et al., 1980; Lubitz et al., 1985). Chlorophyll derivatives with a $20-\mathrm{OH}$ substituent are unknown. If judged from their fully unsaturated analogues, their properties should, however, be rather different as compared to methylpheophorbide-RCI. The 20-hydroxy-porphyrins 

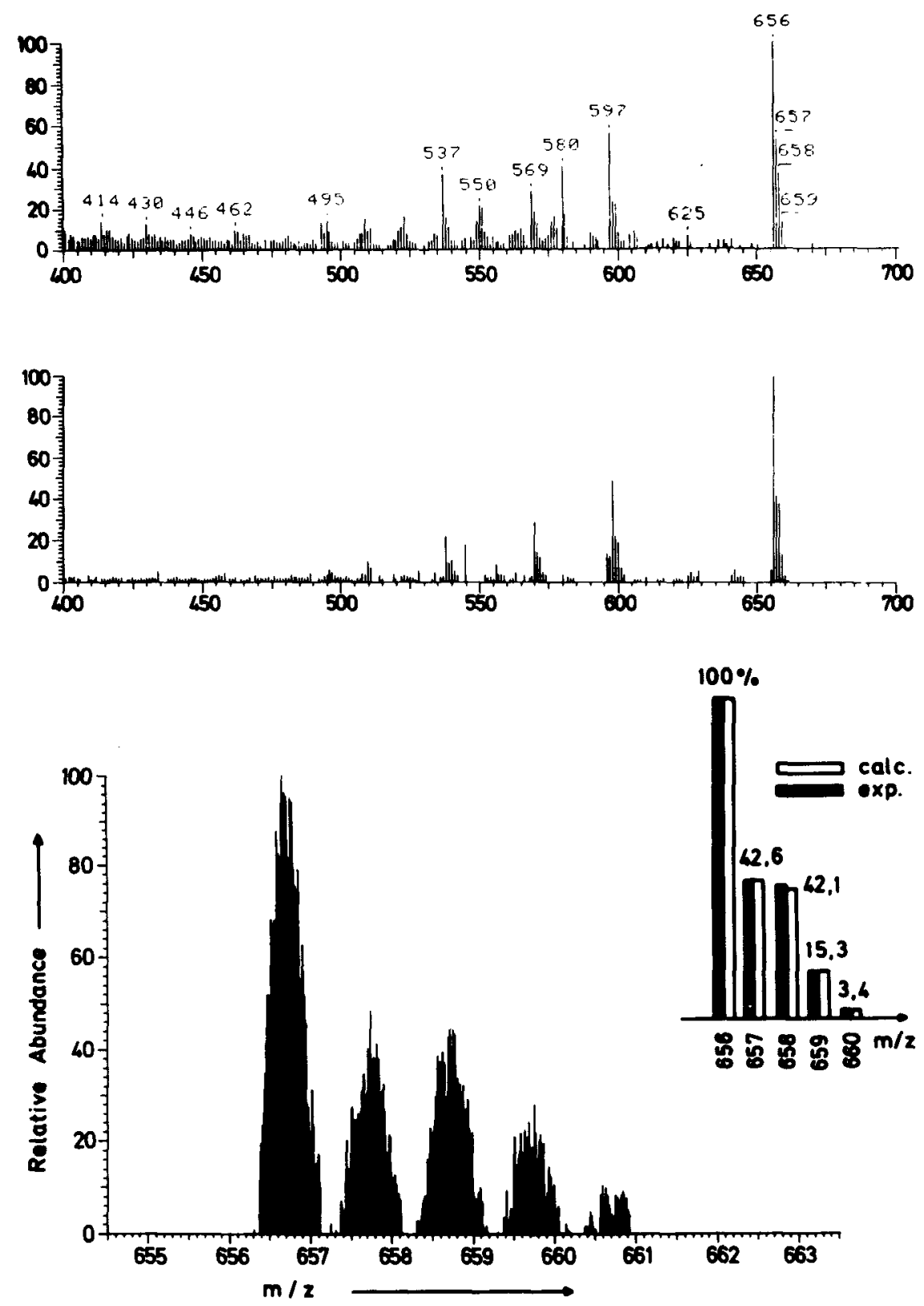

Figure 3. Mass spectra of (A) natural methylpheophorbide-RCI (fraction B), and (B) of $13^{2}$ S-hydroxy20-chloro-methyl-pheophorbide $a$ obtained by electron impact ionization. (C) Molecular ion region of the field-desorption mass spectrum (25 mA heating current) of natural methylpheophorbide-RCI. D: Comparison of the measured intensities (averaged from three separate runs) and the intensities calculated for the formula $\mathrm{C}_{36} \mathrm{H}_{37} \mathrm{~N}_{4} \mathrm{O}_{6} \mathrm{Cl}$. The direct isotope determination was performed as described previously (Schiebel and Schulten, 1985).

tautomerize readily to the 20-oxophlorins which exhibit a radically changed absorption spectrum. Due to the facile one-electron oxidation, the NMR spectra of oxophlorins are generally very broadened if observable at all (Fuhrhop, 1975). If these properties are not quite different in the 17,18 dihydroporphyrins, the results are only compatible with $\mathrm{Cl}$ at $\mathrm{C}-20$ and $\mathrm{OH}$ at $\mathrm{C}-13^{2}$.
Synthesis of methylpheophorbide-RCI from chlor. ophyll a

Oxygenation at $\mathrm{C}-13^{2}$ is a classical reaction of chlorophylls (see Fischer and Orth, 1940; Wolf and Scheer, 1972; Schaber et al., 1984; Hynninen and Lötjönen, 1981). Schmidt (1985) has recently reported, that $13^{2}$-hydroxy-pheophorbides are formed 

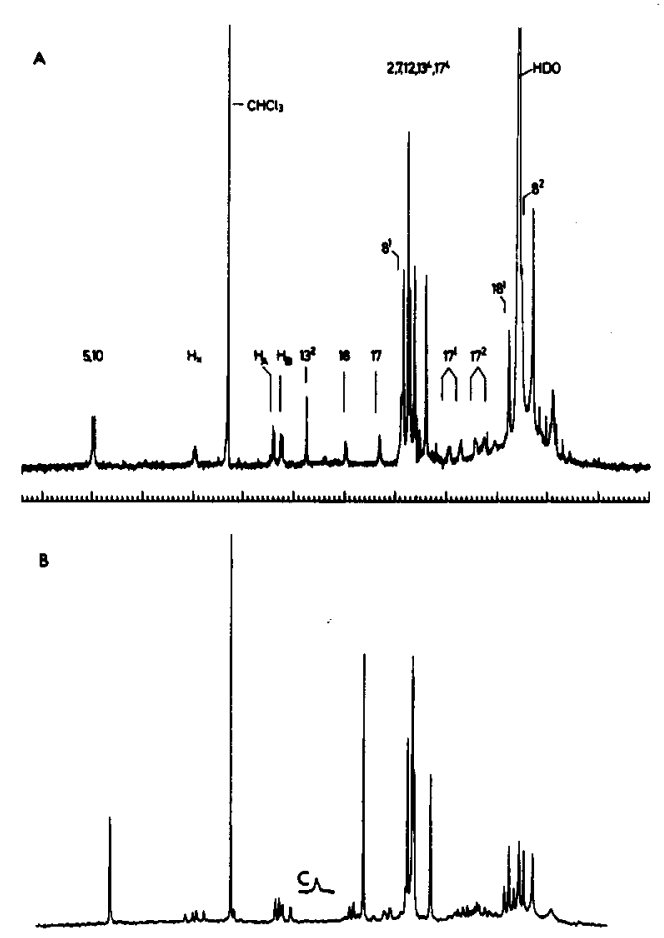

10 o[ppm]

0

Figure 4. Proton NMR spectra of (A) natural methylpheophorbide-RCI fraction B (c $=80 \mu M$ taken at 500 $\mathrm{MHz}$ ) and (B) of $13^{2} \mathrm{~S}-\mathrm{hydroxy}-20$-chloromethylpheophorbide $a(c=4 \mathrm{~m} M$ taken at $80 \mathrm{MHz})$. The peak was assignments are indicated in the upper spectrum. Both spectra in $\mathrm{C}^{2} \mathrm{HCl}$. Insert $\mathrm{C}$ shows the region of the $13^{2}-\mathrm{OH}$ signal before ${ }^{1} \mathrm{H}^{2} \mathrm{H}$-exchange with ${ }^{2} \mathrm{H} \mathrm{O}$, the full spectra $(A, B)$ were taken after the exchange. All other signals were unchanged.

in good yield during the complexation with zinc in the presence of air. This method was used for the formation of $13^{2}$-hydroxy-methylpheophorbide $a$, which is isolated in $30 \%$ yield after demetalation with hydrochloric acid. The two epimers $\left(13^{2} R, S\right)$ can be analyzed by HPTLC. They were not separated before the chlorination reaction, which was done by the procedure of Woodward and Skaric (1967). In a biphasic system containing diethylether and aqueous hydrochloric acid, the pheophorbides are treated at room temperature with hydrogen peroxide. The acid concentration is adjusted such that the educt is just transferred to the acid phase, and the less basic 20-chloro product is transferred to the ether phase. The reaction is complete, if the aqueous phase is colorless or nearly so.

The epimeric mixture of $13^{2}$-hydroxy-methylpheophorbide $a$ yields eventually (see below) two epimeric $13^{2}$-hydroxy-20-chloro-methylpheophorbides $a$, which were separated by a combination of reverse-phase HPLC and preparative tlc. The one formed in higher yield $(9 \%)$ is identical with fraction $\mathrm{B}$ of methylpheophorbide- $\mathrm{RCI}$ according to its chromatographic properties, the other one $(0.4 \%$ isolated yield) to fraction $\mathrm{A}$. The mass spectra of the two major components are identical. The NMR spectrum of the major synthetic product lacks the $20-\mathrm{H}$ signal and has the $13^{2}-\mathrm{OH}$ resonance at $\delta=5.75$ $\mathrm{ppm}$. There are, however, distinct chemical shift differences for many signals if compared to fraction $B$ of methylpheophorbide-RCI. The two products are nonetheless considered identical, because the proton NMR spectra of cyclic tetrapyrroles are strongly concentration dependent (Scheer and Katz, 1975) and the two spectra had to be taken at concentrations differing by almost two orders of magnitude due to technical reasons. To test the aggregation shifts in 20-chlorinated pigments, we have recorded the NMR of spectrum 20-chloro-pyromethylpheophorbide $a$ at 3 different concentrations (Table 1). The observed chemical differences are comparable to those of the respective resonances between the synthetic and natural methylpheophorbide-RCI.

A noteworthy and hitherto unreported observation has been made during the chlorination studies. The product(s) first formed during the chlorination have the the same absorption spectra as the reaction products finally isolated after work-up, but are slightly different chromatographically. Thus, pyromethylpheophorbide $a$ yields first a product which is slightly more mobile on silica and on reverse phases, than the final product, e.g. 20-chloropyromethylpheophorbide $a$. This first product is unstable and generally already accompanied by the final one, to which it is slowly transformed during work-up. The transformation is accelerated, if the tlc plates used for separation are dried completely after development, while it is usually preferential in chlorophyll chemistry to scrape-off the separated zones while the plates are still wet to prevent unwanted side reactions. Similarly, two precursors are formed after chlorination of the epimer mixture of $13^{2}$-hydroxymethylpheophorbide $a$, which are transformed under the same conditions to the final products. Preliminary data obtained for the intermediates during the reaction with methylpheophorbide $a$, indicate the presence of more than one $\mathrm{Cl}$ substituent. The mass spectrum has a molecular ion corresponding to a doubly chlorinated methylpheophorbide $a$ (see materials and methods). It has only in one case been possible to obtain an NMR spectrum of such intermediate, e.g. from the chlorination reaction of $13^{2}$-hydroxy-methylpheophorbide $a$. The spectrum is only in part interpretable due to the presence of more than one compound. However, it is clearly lacking all resonances related to the vinyl group. Since these signals occur in chlorophylls in regions unobstructed by other signal, this indicates the vinyl group as the second point to chlorination. The transformation to the final, 20-monochlorinated species would then involve the elimination of hydrochloric acid to restore the vinyl group. 
Table 1. ${ }^{1} \mathrm{H}-\mathrm{NMR}$ spectra of 20 -chloro-pheophorbides in chloroform

\begin{tabular}{lcc}
\hline Signal & $\begin{array}{c}\text { 20-Chloro-pyromethyl- } \\
\text { pheophorbide } a\end{array}$ & Methylpheophorbide-RCI \\
\hline $5-\mathrm{H}$ & -0.35 & -0.30 \\
$10-\mathrm{H}$ & -0.37 & -0.25 \\
vinyl-Hx & +0.03 & 0 \\
vinyl-Ha & -0.06 & -0.05 \\
vinyl-Hb & -0.02 & -0.05 \\
$13^{2}-\mathrm{H}$ & -0.05 & - \\
$13^{2}-\mathrm{OH}$ & - & -0.25 \\
$17-\mathrm{H}$ & -0.12 & -0.15 \\
$18-\mathrm{H}$ & -0.10 & -0.15 \\
$13^{4}-\mathrm{CH}_{3}$ & - & -0.05 \\
$17^{4}-\mathrm{CH}_{3}$ & 0 & 0 \\
$2-\mathrm{CH}_{3}$ & -0.12 & -0.10 \\
$8^{1}-\mathrm{CH}_{3}$ & -0.07 & -0.10 \\
$18-\mathrm{CH}_{3}$ & 0 & 0 \\
\hline
\end{tabular}

Dilution shifts ( $\Delta \delta$ in ppm) of 20 -chloro-pyromethylpheophorbide $a$, and chemical shift differences between synthetic and natural methylpheophorbide- $\mathrm{RCI}$ obtained at different concentrations. A negative sign denotes a low-field shift upon dilution. Shifts are only given for signals which are unambiguously assigned by their multiplicities and/or positions in the spectrum.

\section{Stereochemistry}

The gross features of the cd spectra of methylpheophorbide-RCI are similar to those in methylpheophorbide $a$. Since the signs of the major cd bands are determined by the absolute configuration at C-17 (Wolf and Scheer, 1973), and the relative stereochemistry at $\mathrm{C}-17, \mathrm{C}-18$ is not affected by reaction sequence from chlorophyll $a$ to $13^{2}$-hydroxy20-chloro-methylpheophorbide $a$, the latter has the "normal" $17 \mathrm{~S}, 18 \mathrm{~S}$ configuration. The circular dichroism of methylpheophorbide-RCI was in the beginning puzzling, because it varied in different preparations. These variations could then be related to the presence of two epimers which differed in their stereochemistry at $\mathrm{C}-13^{2}$. The absolute configuration can be deduced from a comparison of the two isomers of the synthetic product (Table 2 and Fig. 5). The stereochemistry of epimeric $13^{2} \mathrm{R}, \mathrm{S}$-(alk)oxypheophorbides has been investigated by circular dichroism spectroscopy (Wolf and Scheer, 1973; Hynninen, 1981). They differ significantly in almost every part of the spectrum. The $Q x$ band around 530 $\mathrm{nm}$ much more intense in the $13^{2} \mathrm{R}$ epimers, the fine structure of the Soret band system is different leading also to a more intense and narrow redmost band around $414 \mathrm{~nm}$ in the $13^{2} \mathrm{R}$-epimer, and the signs of most UV bands are opposite. The spectra of the two $13^{2} \mathrm{R}, \mathrm{S}$-hydroxy-methylpheophorbides (Schmidt, 1985) are almost superimposable to the spectra of the corresponding $13^{2} \mathrm{R}, \mathrm{S}$-methoxy-methylpheophorbides (Wolf and Scheer, 1973) thus providing an

Table 2. Circular dichroism spectra of epimeric $13^{2} \mathrm{R}, \mathrm{S}$-oxy-pheophorbides

\begin{tabular}{|c|c|c|c|c|c|}
\hline \multicolumn{2}{|c|}{$\begin{array}{l}13^{2} \text {-Hydroxy- } \\
\text { methylpheophorbide } a\end{array}$} & \multicolumn{2}{|c|}{$\begin{array}{l}13^{2} \text {-Hydroxy-20-chloro- } \\
\text { methylpheophorbide } a^{*}\end{array}$} & \multicolumn{2}{|c|}{ Methylpheophorbide-RCI } \\
\hline $13^{2} \mathrm{R}$ & $13^{2} \mathrm{~S}$ & $13^{2} \mathrm{R}$ & $13^{2} \mathrm{~S}$ & Fract. A & Fract. B \\
\hline $\begin{array}{l}660(-34.7) \\
534(+4.3) \\
508(-3.3) \\
407(+29.3) \\
385(+29.5) \\
353(-14.0) \\
324(+14.0) \\
281(+34.0) \\
257(+26)\end{array}$ & $\begin{array}{l}660(-48.4) \\
535(+39.5) \\
500(+8.0) \\
412(122.7) \\
376(-38.7) \\
329(+12.9) \\
281(-45.2) \\
254(-42)\end{array}$ & $\begin{array}{l}679(-36.4) \\
545(+10.4) \\
\\
414(+57.3) \\
395(+52.9) \\
\\
336(+22.8) \\
281(+18.2) \\
252(+21.2) \\
230(-30.9)\end{array}$ & $\begin{array}{l}679(-43.6) \\
545(+39.6) \\
\\
414(130.5) \\
375(-24.8) \\
\\
336(+28.4) \\
284(-44.9) \\
239(-34.5)\end{array}$ & $\begin{array}{l}679(-38) \\
547(+34) \\
\\
416(+136) \\
375(-13) \\
337(+10) \\
285(-60)\end{array}$ & $\begin{array}{l}679(-21.5) \\
546(+7.8) \\
512(-3) \\
410(+54.1) \\
392(+44.8) \\
\\
335(+14.9) \\
281(+8.8) \\
250(+13.3) \\
230(-23.3)\end{array}$ \\
\hline
\end{tabular}

*Data from B. Schmidt (1985).

Molar ellipticities $\left([8] \times 10^{3}\right)$ of the major bands. The molar extinction coefficients of the methylpheophorbide-RCI epimers have been assumed as 60000 . See also Fig. 5. 

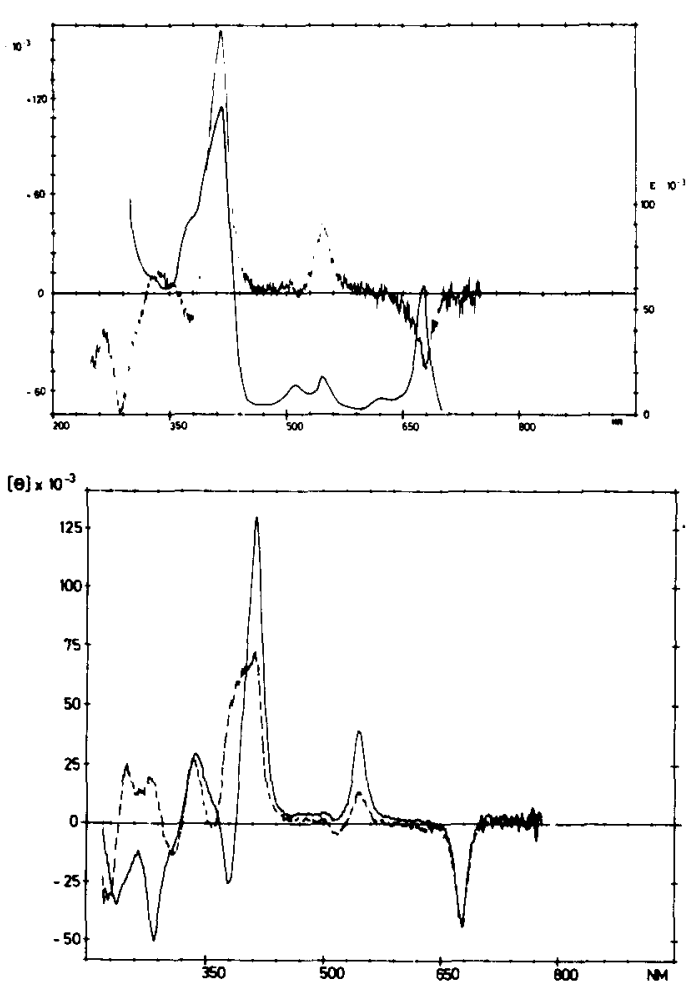

Figure 5. A: Circular dichroism and UV-Vis absorption spectra of methylpheophorbide-RCI (fraction A). B: Circular dichroism spectra of the epimeric $13^{2} \mathrm{R}$ - and $13^{2} \mathrm{~S}$ hydroxy-20-chloro-methylpheophorbides $a$. Spectra taken methanol. The extinction coefficient of the "red" band of methylpheophorbide-RCI has been assumed to $60000 \mathrm{M}^{1}$ $\mathrm{cm}^{1}$, and the molar ellipticities are based on this value.

assignment of the former. The spectra of the two $13^{2} \mathrm{R}, \mathrm{S}$-hydroxy-methylpheophorbides $a$ (Schmidt, 1985 ) are also pairwise similar to the $13^{2}$-hydroxy-20chloro-methylpheophorbides $a$ (Fig. 5), except for a small red-shift of the chlorinated products. This provides in turn an assignment of the stereochemistry at $\mathrm{C}-13^{2}$ of the latter in such a way, that the major product has the $13^{2} \mathrm{~S}$-configuration. This corresponds to the same orientations of the substituents as in the "normal" $13^{2} \mathrm{R}$-chlorophyll $a$, because the introduction of an oxy-substituent at $\mathrm{C}-13^{2}$ changes its absolute configuration in the Cahn-Ingold-Prelog notation. The spectrum of fraction $B$ of methylpheophorbide- $\mathrm{RCI}$ is similar to that of the synthetic $13^{2} \mathrm{~S}$-product (Fig. 5), its structure is thus $13^{2} \mathrm{~S}$ hydroxy-20-chloro-methylpheophorbide $a$. Similarly, the spectrum of the minor fraction A (which was the predominant isomer isolated by method III from prepurified chlorophyll-RCI) is identical to that of the synthetic $13^{2} R$-product with unnatural configuration.

\section{DISCUSSION}

The structure of methylpheophorbide-RCI has been established by spectroscopic techniques and partial synthesis as $13^{2} \mathrm{~S}$-hydroxy-20-chloromethylpheophorbide $a$. We have chosen to work with the methylpheophorbide rather than with the genuine chlorophyll-RCI because the former is less prone to degradation and side reactions during the tedious isolation, and because some of the spectroscopic techniques (mass spectra, circular dichroism) are easier to apply and/or the results better to interpret due to a large number of reference spectra available. This structure identification poses several questions: Firstly: what is the relationship of the isolated methylpheophorbide to chlorophyll-RCI, secondly: is the chlorophyll- $\mathrm{RCI}$ present as such in situ or is it modified during the extraction, and thirdly: what is the function of chlorophyll-RCI in vivo. The questions have to be answered in this sequence, and presently only the first one can be answered with confidence.

Relationship of methylpheophorbide-RCI, chlorophyll-RCI "isolated" and chlorophyll-RCI in situ

Both the chlorination at C-20 (Woodward and Skaric, 1963; Hynninen and Lötjönen, 1981) and the hydroxylation at $\mathrm{C}-13^{2}$ (Brereton et al., 1980; Lubitz et al., 1985; Schaber et al., 1984) are common reactions of chlorophyllous pigments which occur under mild conditions and often inadvertently. One then has to consider the possibility, that the isolated product is not identical to the one present in situ. This isolation proceeds in two steps: Extraction of the chlorophylls, and then derivatization to the methylpheophorbides. Since the derivatization produces the same pigment, albeit in different yield, irrespective of the liberal use or strict omission of chlorinated reagents and solvents, an artefact formation during the derivatization is excluded. The different yields (decrease by $40 \%$ ) after omission of chlorinated solvents from the chromatographies, is most likely due to the decreased resolving power of these mobile phases and the resulting losses during purification. The inadvertent introduction of one or both of the new substituents into chlorophyll $a$ during methylpheophorbide formation is also excluded by our finding of the same methylpheophorbide-RCI when starting from authentic chlorophyll- $\mathrm{RCI}$ provided to us by Dörnemann and Senger, and from the crude chlorophyll extract of Spirulina geitleri. This indirect evidence is substantiated by the results obtained by Dörnemann and Senger (1986) for the chlorophyll$\mathrm{RCI}$ proper in the accompanying paper. The structure of isolated chlorophyll-RCI is then $13^{2}$-hydroxy20-chloro-chlorophyll $a$.

The relationship to the pigment(s) in situ is presently much more difficult to answer. The photosynthetic membrane has a high affinity to chloride ions, and a biosynthetic route to chlorophyll-RCI can readily be suggested by the involvement of enzymes producing hypochlorite. Natural chlorinated, but also brominated and iodinated compounds arising 


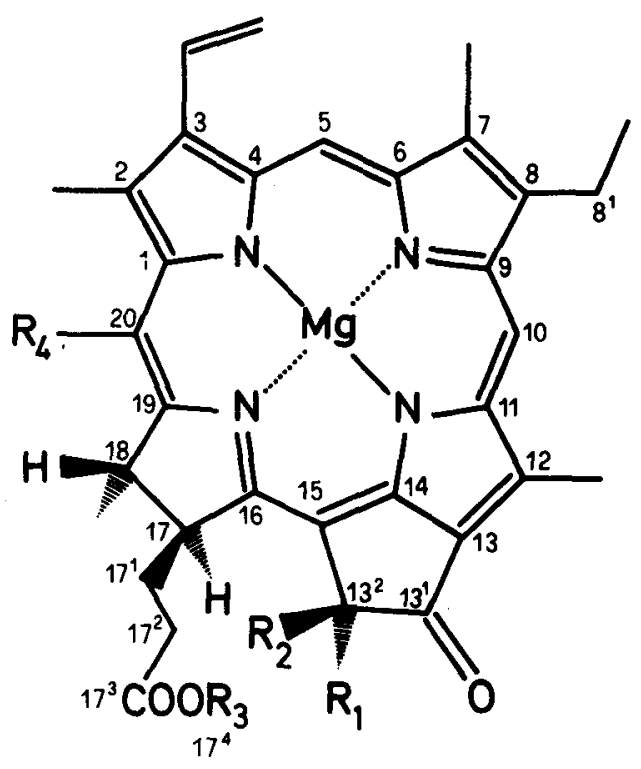

$\begin{array}{lllll}\text { Chlorophyll } a: & \mathbf{R}_{1}=\mathrm{COOCH}_{3} & \mathbf{R}_{2}=\mathbf{H} & \mathbf{R}_{3}=\text { Phytyl } & \mathbf{R}_{4}=\mathbf{H} \\ \text { Chlorophyll-RCI: } & \mathbf{R}_{1}=\mathrm{COOCH}_{3} & \mathbf{R}_{2}=\mathrm{OH} & \mathbf{R}_{3}=\text { Phytyl } & \mathbf{R}_{4}=\mathrm{Cl}\end{array}$

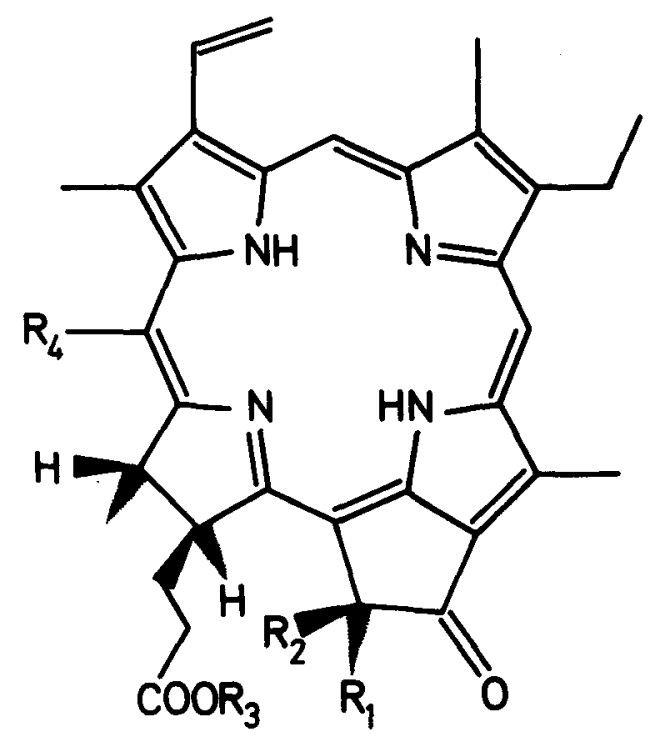

Pheophytin $a$ :

132-hydroxy-20-chloro-pheophytin $a$ : Methylpheophorbide $a$ :

20-Cl-methylpheophorbide $a$ :

$13^{2} \mathrm{~S}$-hydroxy-methylpheophorbide $a$ :

$13^{2} \mathrm{R}$-hydroxy-methylpheophorbide $a$ :

$13^{2}$ S-hydroxy-20-chloro-methylpheophorbide $a$ :

$13^{2} \mathrm{R}$-hydroxy-20-chloro-methylpheophorbide $a$ :

Pyromethylpheophorbide $a$ :

20-Chloro-pyromethylpheophorbide $a$ :

from electrophilic substitution type reactions are found in many organisms and are in particular abundant in marine plants (Moore, 1978). Several enzymes with this activity have been studied in some detail (chloroperoxidases, Thoma et al., 1970; Champion et al., 1975; myeloperoxidases, Harrison and

\begin{tabular}{|c|c|c|}
\hline $\mathbf{R}_{1}$ & $\mathbf{R}_{\mathbf{2}}$ & $\mathrm{R}_{3}$ \\
\hline $\mathrm{COOCH}_{3}$ & $\mathrm{H}$ & Phytyl \\
\hline $\mathrm{COOCH}_{3}$ & $\mathrm{OH}$ & Phytyl \\
\hline $\mathrm{COOCH}_{3}$ & $\mathrm{H}$ & $\mathrm{CH}_{3}$ \\
\hline $\mathrm{COOCH}_{3}$ & H & $\mathrm{CH}_{3}$ \\
\hline $\mathrm{COOCH}_{3}$ & $\mathrm{OH}$ & $\mathrm{CH}_{3}$ \\
\hline $\mathrm{OH}$ & $\mathrm{COOCH}_{3}$ & $\mathrm{CH}_{3}$ \\
\hline $\mathrm{COOCH}_{3}$ & $\mathrm{OH}$ & $\mathrm{CH}_{3}$ \\
\hline $\mathrm{OH}$ & $\mathrm{COOCH}_{3}$ & $\mathrm{CH}_{3}$ \\
\hline $\mathrm{H}$ & H & $\mathrm{CH}_{3}$ \\
\hline
\end{tabular}

Schultz, 1976). It should be noted, that both isomers are found in varying ratios, which may however be related to the extensive isolation procedures. $\mathrm{C}-13^{2}$ is not enolizable in $13^{2}$-oxy-methylpheophorbides and can only be epimerized under acidic conditions, which would indicate a loose enzymatic control. A 
stronger enzymatic control of chlorophyll-RCI formation is on the other hand suggested by the failure to isolate the respective brominated chlorophyll upon chloride starvation of Scenedesmus in a bromide rich medium (Dörnemann and Senger, 1984). A non-random chlorination of chlorophyll $a$ is furthermore indicated by the very close quantitative relationship between the amount of $\mathrm{P} 700$ and the yield of chlorophyll-RCI extracted from a variety of photosynthetic organisms (Dörnemann and Senger, 1985). This leaves as the conclusion, that either chlorophyll-RCI is a constituent of photosystem I reaction centers, or one of its constituents is selectively and quantitatively converted to chlorophyll-RCI during the extraction. Obviously, this question can only be answered by non-invasive techniques which are in progress.

\section{Function of chlorophyll-RCI}

On chemical grounds, it is presently difficult to rationalize the structure of chlorophyll-RCI as the structure of the primary donor, P700. All 20chlorinated chlorophylls have a decreased fluorescence lifetime, and hence a decreased lifetime of the first excited singlet state. A low fluorescence yield is common for reaction center pigments, because they are optimized for fast photochemistry. However, this does not necessarily require a decreased lifetime of the excited state, because any radiationless decay would compete with the photochemistry as well. In nature, both extremes are found. The nonfluorescent retinal is used for the efficient photochemistry in rhodopsins and bacteriorhodopsins, and the highly fluorescent bacteriochlorophyll is present in bacterial reaction centers. More difficult to reconcile with its function as a primary donor is the sluggish oxidation of chlorophyll-RCI (Dörnemann and Senger, 1982) and its demetalated derivatives (Scheer $e t$ al., unpublished), as compared to the respective 20-unsubstituted pigments. This property is just opposite to what is expected for a primary donor. It would, however, be well compatible with the properties of an electron acceptor. Bacteriochlorophylls and/or -pheophytins are well established as the primary acceptors in bacterial photosynthesis (see Parson, 1982) and there is good evidence that chlorophyllous pigments are also the primary electron acceptors of photosystems I and II (Fajer et al., 1980; Klimov and Krasnovskii, 1981). Again, these questions can only be answered by non-invasive spectroscopic techniques. It should also be kept in mind, that the chemistry of 20-chlorinated chlorophylls is as yet only partly explored. The accessibility of chlorophyll-RCI by chemical (vide supra) or enzymatic synthesis opens the way for systematic investigations along these lines. It allows for the first time the preparation of sufficient material to develop useful selective spectroscopic criteria, and to study its chemistry in more detail.
Notes added in proof: Fujita et al have recently reported preliminary results on the redox, optical and ESR characteristics of 20-chloro-chlorophyll $a$ as well as of its cation and anion radicals. (Fujita, E., J. Fajer, B. Chadwick, H. Frank, D. Simpson, and K. M. Smith, Biophys. Soc. Meeting, Feb. 1986). They did not find significant diagnostic signatures for an identification and distinction from Chl $a$ with these techniques. We are aware of the recent suggestion of yet another modified pigment to be present in $\mathrm{RCI}$, e.g. chlorophyll $a^{\prime}$, (Watanabe, T., M. Kobayashi, A. Hongu, M. Nakazato, T. Hiyama and N. Murata (1985) FEBS Lett. 191, 252-256).

Acknowledgements-This work was in part supported by the Deutsche Forschungsgemeinschaft, Bonn (H.S.: SFB 143 and Ru128/24-1; H.-R.S.: Schu 416/8-1; H.-M.S.: Schi 168/4, S.S.: Ru 128/24-1). We are indebted to D. Dörnemann and $H$. Senger for providing us with samples of authentic chlorophyll-RCI and open discussions of all results prior to publication. We thank $H$. H. Inhoffen for the gift of pheophytin 'Sandoz', and P. Hynninen for the communication of unpublished material on 20 chloromethylpheophorbide $a$. The expert technical assistance of $H$. Wieschhoff is acknowledged. We thank W. Rüdiger and F. Dörr for continuing support and S. Schoch for stimulating discussions. We acknowledge the help of Dr. V. Formacek (Bruker, Karlsruhe) for the opportunity to use the WH500 NMR spectrometer.

\section{REFERENCES}

Bazzaz, M. B. and R. G. Brereton (1983) 4-vinyl-4desethyl chlorophyll- $a$. A new naturally occurring chlorophyll. FEBS Lett. 138, 104-108.

Boxer, S. G., C. E. D. Chidsey and M. G. Roelofs (1983) Magnetic-field effects on reaction yield in the solid state. An example from photosynthetic reaction centers. Ann. Rev. Phys. Chem. 34, 389-417.

Brereton, R. G., V. Rajanada, T. J. Blake, J. K. M. Sanders and D. H. Williams (1980) "In beam" electron impact mass spectroscopy: the structure of a bacteriochlorophyll allomer. Tetrahedr. Lett. 1671-1674.

Bucks, R. R. and S. G. Boxer (1982) Synthesis and spectroscopy properties of a novel cofacial chlorophyllbased dimer. J. Am. Chem. Soc. 104, 340-343.

Budzikiewicz, H. (1978) Mass spectra of Porphyrins and related compounds. In The Porphyrins (Edited by D. Dolphin), Vol. III, chapter 9. Academic Press, New York.

Budzikiewicz, H. and K. Taraz (1971) Chlorophyll c. Tetrahedron 27, 1447-1460.

Champion, P. M., R. Chiang, E. Münck, P. Debrunner and L. P. Hager (1975) Mössbauer investigations of highspin-ferrous heme proteins. II. Chloroperoxidase, horseradish peroxidase and hemoglobin. Biochemistry 14, 4159-4164.

Cogdell, R. J. (1983) Photosynthetic reaction centers. Annu. Rev. Plant Physiol. 34, 21-45.

Davis, R. C., S. L. Ditson, A. F. Fentiman and R. M. Pearlstein (1981) Reversible wavelength shifts of chlorophyll induced by a point charge. J. Am. Chem. Soc. 103, 6823-6826.

Deisenhofer, J., O. Epp, K. Miki, R. Huber and H. Michel (1984) X-ray structure analysis of a membrane protein complex. Electron density map of the chromophores of the photosynthetic reaction centers from Rhodopseudomonas viridis. J. Mol. Biol. 180, 385-398. Denblanken, H. J. and B. A. Diner (1983) High- 
resolution triplet-minus-singlet absorbance difference spectrum of photosystem-II particles. FEBS Lett. 157, 21-27.

Diner, B. A. and F. A. Wollman (1980) Isolation of highly active photosystem II particles from a mutant of Chlamydomonas reinhardtii. Eur. J. Biochem. 110, 521526.

Dismukes, G. C., K. Ferris and P. Watnick (1982) Electron-paramagnetic-resonance spectroscopic evidence for a tetranuclear manganese cluster as the site for photosynthetic oxygen evolution. Photobiochem. Photobiophys. 3, 243-256.

Dörnemann, D. and H. Senger (1981) Isolation and partial characterization of a new chlorophyll associated with the reaction centre of photosystem I of Scenedesmus. FEBS Lett. 126, 323-327.

Dörnemann, D. and H. Senger (1982) Physical and chemical properties of chlorophyll-RCI extracted from photosystem I of spinach leaves and from green algae. Photochem. Photobiol. 35, 821-826.

Dörnemann, D. and H. Senger (1984) The novel chlorophyll RCI associated with photosystem I. In Advances in Photosynthesis Research (Edited by C. Sybesma), pp. 77-88. Nijhoff/deJunk, The Hague.

Dörnemann, D. and H. Senger (1985) Optical properties and structure of chlorophyll RCl. In Optical Properties and Structure of Tetrapyrroles (Edited by G. Blauer and H. Sund), pp. 589-605. de Gruyter, Berlin.

Dougherty, R. C., H. H. Strain, W. A. Svec, R. A. Uphaus and J. J. Katz (1970) The structure, properties and distribution of chlorophyll c. J. Am. Chem. Soc. 92, $2826-2833$

Fajer, J., D. C. Borg, A. Forman, R. H. Felton, L. Vegh and D. Dolphin (1973) Ann. N.Y. Acad. Sci. 206, 349-364.

Fajer, J., M. S. Davis, A. Forman, V. V. Klimov, E. Dolan and B. Ke (1980) Primary electron acceptors in plant photosynthesis. J. Am. Chem. Soc. 102, 7143-7145.

Falk, H., G. Hoornaert, H. P. Isenring and A. Eschenmoser (1975) Ueber Enolderivate der Chlorophyllreihe. Darstellung von 13.2, 17.2 Cyclophäophorbid Enolen Helv. Chim. Acta 58, 2347-2356.

Feher, G., A. J. Hoff, R. A. Isaacson, and L. C. Ackerson (1975) Ann. N. Y. Acad. Sci. 244, 239-249.

Feher, G. and M. Y. Okamura (1978) Chemical composition and properties of reaction centers. In The Photosynthetic Bacteria, (Edited by R. K. Clayton and W. R. Sistrom), Ch. 19. Plenum Press, New York.

Fischer, H. and A. Stern. In Die Chemie des Pyrrols (Edited by H. Fischer and H. Orth), Vol. 2, 2nd half.

Franck, J. (1961) in McElroy, W. D. and B. Glass (Eds) Light and Life, Discussion contribution on pp. 386-391. John Hopkins Press, Baltimore.

Fuhrhop, J. H. (1975) Irreversible reactions at the porphyrin periphery. In Porphyrins and Metalloporphyrins (Edited by K. M. Smith), pp. 625-666. Academic Press, New York.

Ganago, I. B., V. V. Klimov, A. O. Ganago, V. A. Shuvalov and Y. E. Erokhin (1982) Linear dichroism and orientation of pheophytin, the intermediary electronacceptor in photosystem II reaction centers. FEBS Lett. 140, $127-130$.

Haehnel, W. (1984) Photosynthetic electron transport in higher plants. Ann. Rev. Plant Physiol. 35, 659-693.

Harrison, J. E. and J. Schultz (1976) Studies on the chlorinating activity of myeloperoxidase. J. Biol. Chem. 251, 1371-1374.

Hoff, A. J. (1982) ESR and ENDOR of primary reactants in photosynthesis. Biophys. Struct. Mech. 8, 107150.

Holt, A. S., D. W. Hughes, H. J. Kende and J. W Purdie (1962) Studies of chlorobium chlorophylls $v$ chlorobium chlo:ophylls (660). J. Am. Chem. Soc. 84, 2835-2836.
Holt, A. S. and H. V. Morley (1959) A proposed structure for chlorophyll d. Can. J. Chem. 37, 507-514. Huang, C. and D. S. Berns (1981) Isolation of P700 chlorophyll-protein complex from a blue-green alga by a nondetergent method. Biochem. Biophys. Res. Comm. 351-358.

Hynninen, P. H. (1981) Mechanism of the allomerization of chlorophyll inhibition of the allomerization by carotenoid pigments. Z. Naturforsch. 36b, 1010-1016.

Hynninen, P. H. and S. Lötjönen (1981) Electrophilic substitution at the $\delta$-methinebridge of pheophorbide a and $\mathrm{a}^{\prime}$. Tetrahedron Lett. 1845-1846.

Hynninen, P. H. and G. Sievers (1981) Conformations of chlorophylls $a$ and $a^{\prime}$ and their magnesium-free derivates as revealed by circular-dichroism and proton magnetic-resonance. $Z$. Naturforsch. 36b, 1000-1009.

Ikegami, I. and S. Katoh (1975) Biochim. Biophys. Acta 376, 588-592.

Ikegami, I. and B. Ke (1984) A 160kDa photosystem-I reaction-center complex: Low-temperature absorption and EPR spectroscopy of the early electron acceptors. Biochim. Biophys. Acta 764, 80-85.

Isenring, H. P., E. Zass, K. Smith, H. Falk, J. L. Luisier and A. Eschenmoser (1975) Enolisierte Derivate der Chlorophyllreihe: 13-Desmethoxycarbonyl-17-desoxycyclo-chlorophyllid-a-enol und eine Methode zur Einführung von Magnesium unter milden Bedingungen. Helv. Chim. Acta 58, 2357-2367.

Katz, J. J., J. R. Norris, L. L. Shipman, M. C. Thurnauer and M. R. Wasielewski (1978) Chlorophyll function in the photosynthetic reaction center. Ann. Rev. Bioeng. 7, 393-434

Ke, B., H. Inoue, G. T. Babcock, Z. X. Fang and E. Dolan (1982) Optical and electron paramagneticresonance characterizations of oxygen-evolving photosystem II sub-chloroplasts fragments isolated from the thermophilic blue-green alga Phormidium-laminosum. Biochim. Biophys. Acta 682, 297-306.

Klimov, V. V. and A. A. Krasnovskii (1981) Pheophytin as the primary electron-acceptor in photosystem-II reaction centers. Photosynthetica 15, 592-609.

Knaff, D. B. (1977) The primary reaction of plant photosystem-II. Photochem. Photobiol. 26, 327-340.

Lubitz, W., F. Lendzian and H. Scheer (1985) Characterisation of 10-Hydroxybacteriochlorophyll a by ENDOR and TRIPLE resonance spectroscopy. J. Am. Chem. Soc. 107, 3341-3343.

Lubitz, W., F. Lendzian, H. Scheer, J. Gottstein, M. Plato and K. Möbius (1984) Structural studies of the primary donor cation radical $\mathrm{P} 870$ in reaction centers of Rhodospirillum rubrum by ENDOR in solution. Proc. Natl. Acad. Sci. USA 81, 1401-1405.

Mauzerall, D. and A. Chivvis (1973) J. Theor. Biol. 42, 387-395.

Moore, R. E. (1978) Algal Nonisoprenoids. In Marine Natural Products (Edited by P. J. Scheuer), pp. 44-124. Academic Press, New York.

Nechushtai, R., P. Muster, A. Binder, V. Liveanu and N. Nelson (1983) Photosystem-I reaction center from the thermophilic cyanobacterium Mastigocladus laminosus. Proc. Natl. Acad. Sci. USA 80, 1179-1183.

Norris, J. R., H. Scheer and J. J. Katz (1978) ENDOR spectroscopy of chlorophylls and the photosynthetic light conversion apparatus. In The Porphyrins (Edited by $\mathrm{D}$. Dolphin), Vol. IV, Ch. 3. Academic Press, New York. Norris, J. R., R. A. Uphaus, H. L. Crespi and J. J. Katz (1971) Electron spin resonance of chlorophyll and the origin of signal-I in photosynthesis. Proc. Natl. Acad. Sci. USA 68, 625-627.

O'Malley, P. J. and G. T. Babcock (1984) The plausibility of monomer structure for P700 and P870 in photosynthetic reaction centers. In Advances in Photosynthesis Research (Edited by C. Sybesma), pp. 1, 6, 697-700. Nijhoff/deJunk, The Hague. 
Parson, W. W. (1982) Photosynthetic bacterial reaction centers: Interactions among the bacteriochorophylls and bacteriopheophytins. Annu. Rev. Biophys. 11, 57-80.

Pennington, F. C., H. H. Strain, W. A. Svec and J. J. Katz (1964) Preparation and properties of pyrochlorophyll a, pyropheophytin a and methylpyropheophorbide a derived from chlorophyll by decarbomethoxylation. J. Am. Chem. Soc. 86, 1418-1426.

Rutherford, A. W. (1981) Reaction center triplet-states in photosystem-I and photosystem-II. Biochim. Biophys. Acta 635, 225-235.

Rutherford, A. W. and P. Mathis (1983) A relationship between the midpoint potential of the primary acceptor and low-temperature photochemistry in photosystem-II. FEBS Lett. 154, 328-334.

Schaber, P. M., J. E. Hunt, R. Fries and J. J. Katz (1984) High-performance liquidchromatography study of the chlorophyll allomerization reaction. J. Chromatogr. 316, 25-41.

Schaffernicht, H. and W. Junge (1981) Analysis of the complex band spectrum of P700 based on photoselection studies with photosystem-I particles. Photochem. Photobiol. 34, 223-232.

Schatz, G. H. and H. T. Witt (1984) Characteristics of electron-transport in oxygen evolving photosystem-II complexes from a thermophylic cyanobacterium Synechococcus. Photobioch. 7, 77-89.

Scheer, H. and J. J. Katz (1975a) New type of Metalcomplexes related to chlorophyll. J. Am. Chem. Soc. 97, 3273-3275.

Scheer H. and J. J. Katz (1975b) Nuclear magnetic resonance spectroscopy of porphyrins and metalloporphyrins. In Porphyrins and Metalloporphyrins (Edited by K. M. Smith), pp. 399-524. Elsevier, New York.

Scheer, H. and J. J. Katz (1978) Peripheral metal complexes: chlorophyll isomers with magnesium bound to the ring E-ketoester system. J. Am. Chem. Soc. 100, 561571 .

Scheer, H., H. Wieschhoff, E. Omiel, B. Nitsche, W. Schäfer, H.-R. Schulten and H.-M. Schiebel (1984) Structure of a methylpheophorbide-RCI. In Advances in Photosynthesis Research (Edited by C. Sybesma), p. II.2. 81-84. Nijhoff/deJunk, The Hague.

Schiebel, H.-M. and H.-R. Schulten (1982) Biomed. Mass Spectrom. 9, 354-362.

Schmidt, B. (1985) Isolierung und Strukturaufklärung von Chlorophyll Abbauprodukten. Dissertation, Universität München.

Senger, H. and V. Mell (1977) Preparation of photosynthetically active particles from synchronized cultures of unicellular algae. In Methods in Cell Biology, Vol. XV, pp. 201-219. Academic Press, New York.

Shuvalov, V. A., E. Dolan and B. Ke (1979) Spectral and kinetic evidence for two early electron acceptors in photosystem I. Proc. Natl. Acad. Sci. USA 76, 770-773.

Smith, K. M., L. A. Kehres and H. D. Tabba (1980) Structures of the bacteriochlorophyll c Homologues: Solution to a longstanding problem. J. Am. Chem. Soc. 102, 7149-7151.

Svec, W. A. (1978) The isolation, preparation, characterization and estimation of the chlorophylls and the bacteriochlorophylls. In The Porphyrins (Edited by D. Dolphin), Vol. V, pp. 341-399. Academic Press, New York.

Thomas, J. A., D. R. Morris and L. P. Hager (1970) Chloroperoxidase: VII. Classical peroxidatic, catalatic, and halogenating forms of the enzyme. J. Biol. Chem. B245, 3129-3134.

Vacek, K., D. Wong and Govindjee (1977) Absorption and fluorescence properties of highly enriched reaction center particles and artificial systems. Photochem. Photobiol. 26, 269-279.

Vierling, E. and R. S. Alberte (1983) P-700 chlorophyll $a$-protein purification, characterization and antibody preparation. Plant Physiol. 72, 634-640.

Wasielewsky, M., J. M. Norris, L. L. Shipman, C. P. Lin and W. A. Svec (1981) Monomeric chlorophyll aenol: evidence for its possible role as the primary electron-donor in photosystem-I of plant photosynthesis. Proc. Natl. Acad. Sci. USA 78, 2957-2961.

Wasielewski, M. (1982) Synthetic approaches to photosynthetic reaction center, structure and function. In Light Reaction Path of Photosynthesis (Edited by F. K. Fong), Ch. 7. Springer, Heidelberg.

Wolf, H. and H. Scheer (1972) Stereochemische Untersuchungen an C-10 disubstituierten C-9 Hydroxyphäophorbiden der a-Reihe. Tetrahedron 28, 5839-5856.

Wolf, H. and H. Scheer (1973) Stereochemistry and chiroptic properties of pheophorbides and related compounds. Ann. N.Y. Acad. Sci. 206, 549-567.

Woodward, R. B. and V. Skaric (1961) J. Am. Chem. Soc. 83, 4676-4677.

Wu, S. M. and C. A. Rebeiz (1984) Molecular structure of protochlorophyllide (E443F625) and of chlorophyllide a (E458F674). Tetrahedr. Lett. 40, 659-664.

Yuasa, M., T. A. Ono and Y. Inoue (1984) Isolation of photosystem-II reaction center complex retaining 33-kDa protein and $\mathrm{MN}$ : a possible structural minimum of photosynthetic O2-evolving system. Photobioch. 7, 2512664 